\title{
Sales Forecasting by Using Exponential Smoothing Method and Trend Method to Optimize Product Sales in PT. Zamrud Bumi Indonesia During the Covid-19 Pandemic
}

\author{
Virgin Wineka Nirmala, Dikdik Harjadi, Robi Awaluddin* \\ Faculty of Economics, University of Kuningan, Indonesia \\ *Corresponding author E-mail: awaluddin.robi@uniku.ac.id
}

Manuscript received 15 August 2021; revised 1 Sept 2021; accepted 15 Sept 2021. Date of publication 4 Nov 2021

\begin{abstract}
Forecasting is important for a company in achieving goals effectively and efficiently. Forecasting aims to determine the next steps to be taken based on historical data. PT. Zamrud Bumi Indonesia is one of the manufacturing companies in the management of agricultural liquid fertilizers with the trademark "Power Bumi". The purpose of this study is to analyze the sales pattern of Power Bumi products during the covid-19 pandemic and compare the forecasting method that is able to produce the smallest error value in forecasting sales of Power Bumi products PT. Zamrud Bumi Indonesia. This study uses 2 methods, namely exponential smoothing and least square trend model. To calculate the error rate using MAD, MSE and MAPE. The results show that the exponential smoothing alpha 0.9 method has the smallest error value compared to other forecasting methods. In forecasting product sales, the MAD value is 130.329 , MSE is 28251.23 and MAPE is $22.00 \%$ with a forecast of 627.628 boxes. Although the exponential smoothing a 0.9 method produces a forecast value that is relatively low than other methods. However, the comparison of products sold and forecasting results has a relatively small average difference (MSE). It can be interpreted that the exponential smoothing a 0.9 method is able to suppress the forecasting error value for the 2nd period. After getting the forecasting results, it can be concluded that the number of products sold for the 2nd covid-19 pandemic period will not differ much from the number of sales in the 1 st covid-19 pandemic period. If the company applies this scientific forecasting method, then sales will be optimal so that excess or shortage of stock can be avoided and the predetermined sales target can be achieved. In addition, the costs incurred during the production process to sales will be more efficient.
\end{abstract}

Keywords: Sales Forecasting, Fertilizer, Exponential Smoothing, Trend, Least Square.

\section{Introduction}

PT. Zamrud Bumi Indonesia which is located in Sumurwiru Sukamaju Village, Cibingbin District, Kuningan Regency, West Java, is a company engaged in the management of liquid fertilizer with the trademark "Power Bumi" has the motto "Tanah Gembur, Tanah Subur, Petani Makmur". In each period PT. Zamrud Bumi Indonesia experienced up-and-down sales (fluctuating) with a difference in numbers that were too far from the specified target. The impact occurs in the buildup of product inventory in the warehouse, irregular inventory management, and the cost of inventory management becomes increasing in other words becomes inefficient. If this continues to happen, the company will continue to suffer losses. In addition, the covid-19 pandemic that has occurred since the beginning of 2020 in Indonesia has a major impact on the economy in Indonesia, especially in terms of demand and product supply [1]. In addition, the covid-19 pandemic caused the world to enter a state of crisis both health crisis and economic crisis. As a result of this virus domestic and foreign trade becomes hampered, due to lockdown (large-scale social restrictions) that result in slow economic growth [2].

The existence of companies engaged in the same industry or the emergence of new companies is one of the factors that threaten and can lead to a decrease in profits [3]. Therefore, to anticipate or deal with problems arising from the sales that are variable and the impact of the covid-19 pandemic, it is necessary to re-plan in determining the number of targets to be achieved. Therefore, this study aims to compare 2 (two) forecasting methods, namely exponential smoothing and least square trend models so that it can be seen methods that are able to produce the smallest error value to then be applied or used by PT. Zamrud Bumi Indonesia.

The exponential smoothing method and the trend-least square method have been widely used in previous studies. In forecasting the sale of fertilizers the trend method gets a success rate above $75 \%$ which means that the method is effective to use because between forecasting 
results and actual sales produce a small value [4]. Then to optimize sales nuget exponential smoothing methods obtain high accuracy values so that it is effective to use [5]. In addition, the exponential smoothing method with $a=0.4$ obtains the smallest MSE value in forecasting the sales of dimsum food dealers [6].

In forecasting meat sales and estimated sales targets the least square trend method has passed the test results in the forecasting system. Sales forecasting is done with 3 stages, namely testing 1 using 3 monthly data, testing 2 using 6 monthly data and 3 testing using 9 monthly data. Once calculated using a system designed to produce the smallest MAPE value of $0.066752122(2 \%)$ with the most number of periods being 9 months. Therefore it can be concluded that the least square method will be better if the amount of data used is more and more, so that the resulting forecasting errors are lower [7]. Least square method to forecast milk sales for the next 1 year and recommend alternatives to procurement of optimal milk supplies in the future. Sales data used from 2014 to August 2019. The results of the data analysis obtained the regression line equation $\mathrm{Y}=275,815.55+599.87 \mathrm{X}$ then obtained sales forecast for 2020 as much as $3,874,864$ liters of dairy milk. It is concluded that the results obtained can be used by KUD Cepigo for optimal milk supply [8]. In addition to the least square method, the exponential smoothing method is also one of the methods that are often used. The accuracy of exponential method forecasting errors can be suppressed or optimized based on the value of their constant (alpha). As in Kumar Paul's research, the constant value (alpha) that is able to suppress the values of MSE, MAD and MAPE is alpha 0.83 and 0.88 so that the forecasting results become optimal [9].

In forecasting the sale of Fertilizer Power Bumi PT. Zamrud Bumi Indonesia will use exponential smoothing method and trend-least square method. Both methods have been widely used in previous studies for example to estimate the number of stationery stocks with alpha 0.7 smallest MAPE values, namely 12.36 have a trend data pattern then the suitable method used should be double exponential smoothing [10]. To strengthen and complement the lack of research Rizal Rachman [11] in predicting the production of the garment industry then in this study the exponential smoothing method will be compared with the least square trend method so that it can be seen methods that are able to optimize sales of Power Bumi fertilizer products. The holding of this research aims to provide benefits to companies and others in the form of solutions and scientific steps in addressing future sales problems based on scientific methods and sources of consideration as well.

\section{Literature Review}

Forecasting is an effort to describe the state of the company in the future. Forecasting is an integral part of planning and control systems, and organizations require forecasting procedures that allow companies to predict the future effectively and in a timely manner [12]. Forecasting is crucial and highly recommended for companies to implement it, because there are many methods of forecasting causal models and effective time series to overcome production, sales and inventory problems [13]. Future events are very difficult to ascertain, so there needs to be a forecasting system that uses the best information as a guide to future activities in order to achieve the goals of the organization [14]. In making sales forecasts depends heavily on the availability of past sales data, If the data collected is more and more then the better the estimate or forecast obtained while if the data collected less then the results of estimates or forecasts will be worse [15]. Before determining the method of forecasting to be compared, it must first be seen the pattern that arises in a data, namely as follows [16]:

1. Horizontal Pattern $(\mathrm{H})$

A horizontal pattern occurs when the data values show that the increase and decrease remain around the average value.

2. Seasonal Pattern (S)

In this pattern is influenced by things that are seasonal. Such as monthly, yearly and so on.

3. Cyclic Pattern (C)

Common in long-term business circles, cyclical data patterns are often affected by economic fluctuations.

4. Trend Pattern (T)

Trend data patterns occur when there is an increase or decrease in the data in the long term.

The main basis of forecasting is the assumption that the kind of data patterns found in the predicted data will be sustainable, so the difference in the ability of forecasting methods in identifying data patterns, requires an effort to adjust between the data patterns that have been estimated in advance with the techniques and forecasting methods used [17]. To get a precise time series method, it is necessary to consider the type of information pattern, so that the testing of a pattern can be done with the most appropriate method [18].

\section{Method}

The research method used is a quantitative method with a descriptive approach. Descriptive approach is intended to describe or describe the results of research on a situation (phenomenon) that is happening clearly without manipulation. The quantitative method with a descriptive approach is able to answer the formulation of the problem relating to the independent variable. Independent variables are independent variables, not independent or dependent variables [19]. As for the final forecasting results, a comparative method will be used, namely the comparison of the final results of the two methods to see the ability of each method in optimizing sales of fertilizer products using several data analysis techniques, Bogdan in [20] explains that data analysis is a step in compiling and finding systematically the data obtained from field notes and other materials, so that it will be easy to understand, and the findings obtained can be informed to the community in need [21]. In this study the pattern of sales data shows a stationary (horizontal) pattern. To predict data with a horizontal pattern, the appropriate and appropriate forecasting method is the exponential smoothing method [13], in the least quadratic trend model method, it is also suitable for minimizing the MSE value. [22].

\subsection{Exponential Smoothing Method}

Exponential Smoothing is a procedure that continuously improves forecasting (smoothing) by averaging the past values of a time series data in an exponential manner [16]. The exponential smoothing method is very popular in supply chain management and business analysis because of its simplicity, transparency, and accuracy [23]. The interesting thing about exponential smoothing is that the most weight is given to the most recent observations. 
$\mathrm{Ft}+1=a \mathrm{Xt}+(1-a) \mathrm{Ft}-1$

information:

$\mathrm{Ft}+1$ : Forecast for period to $\mathrm{t}+1$

$\mathrm{Xt} \quad$ : Period rill value to $\mathrm{t}$ (present)

a : Constant smoothing $(0<\mathrm{a}<1)$

Ft-1 : Forecast for period to $t-1$ (previous)

The determination of constantan (alpha) is determined by trial and error. Alpha values are performed by comparison using intervals between $0<\mathrm{a}<1(0.1$ to 0.9$)$.

\subsection{Trend-Least Square Method}

Trend, i.e. if in a series there is an up or down movement in the long term, then the series is said to be a series that contains elements of a trend. The Least Squares method uses a straight line equation [16]. The equation used is as follows:

$\mathrm{Y}=\mathrm{a}+\mathrm{bx}$

information:

Y: Trend value

$\mathrm{X}$ : Period

a : Constant value $\mathrm{Y}$ if $\mathrm{X}=0$

$\mathrm{b}:$ Constant $\mathrm{x}$ (slop)

Looking for values $\mathrm{a}$ and $\mathrm{b}$ are as follows:

$$
\begin{aligned}
& a=\Sigma y / n \\
& \beta=\Sigma x y / \Sigma x^{2}
\end{aligned}
$$

The period (x) may have different values for the number of odd or even year observations.

\subsection{Calculating Forecasting Errors}

The mean absolute deviation (MAD) is the average of the results of the difference between the actual data and the forecast results during a certain period regardless of whether the forecasting results are greater or less than the reality, with absolute results [24]. MAD is formulated as follows:

$\mathrm{MAD}=\left|\Sigma\left(\mathrm{A}_{\mathrm{t}}-\mathrm{F}_{\mathrm{t}}\right) / \mathrm{n}\right|$

information:

At : Actual data

$\mathrm{Ft}$ : Forecasting in period $\mathrm{t}$

$\mathrm{N}$ : Number of forecasting periods involved

Mean Square Error (MSE) is an alternative method in forecasting but can be quite important because the MSE technique produces moderate errors so it is preferred by a forecaster that produces a very large error. This MSE value is obtained through the difference between the actual value and the forecasting that is squared divided by the number of forecasting time series. MSE values are used when the residual magnitude is evenly distributed throughout the observation [24].

$\operatorname{MSE}=\Sigma\left(\mathrm{A}_{\mathrm{t}}-\mathrm{F}_{\mathrm{t}}\right)^{2} / \mathrm{n}$

information:

At: Actual value of the request

Ft: The value of the forecasting results

$\mathrm{n}$ : Amount of data

Mean Absolute Percentage Error (MAPE) is a measure of relative errors. MAPE is usually more meaningful than MAD because MAPE declares the percentage of errors forecasting results against actual requests over a period that will provide information on the percentage of errors too high or too low [24].

$\mathrm{MAPE}=\Sigma 100\left|\mathrm{~A}_{\mathrm{t}}-\mathrm{F}_{\mathrm{t}}\right| / \mathrm{n}$

information:

At: Actual Request in period $\mathrm{t}$

Ft: Forecasting demand (Forecast) in the period $t$

$\mathrm{n}$ : Number of forecasting periods involved

\section{Results and Discussion}

PT. Zamrud Bumi Indonesia was founded on April 06, 2020, by three founders, Mr. Rusda as Director who was born in Kuningan on February 13, 1964. Mr. Jahid as Deputy Director was born in Brebes on April 20, 1979, and Mr. Kusyanto as The Board of Commissioners was born in Brebes on October 21, 1973. At first, this company was in the form of a CV (Komanditer Company) named CV. Bumi Makmur Raya was established on December 03, 2003, addressed in Cibingbin village Kec. Cibingbin Kab. Kuningan West Java. CV. Bumi Makmur Raya is a supplier of Liquid Organic Fertilizer with the trademarked Power Bumi. Over time and the development of the company was 
decided to change the form of the company into PT (Limited Liability Company) named PT. Zamrud Bumi Indonesia is located in Kampung Sumurwiru Sukamaju Village Kec. Cibingbing Kab. Kuningan West Java. With the change in the shape of the company but not much change in the system in it. As for the future, the company will continue to grow with various other business fields.

In the current market conditions during the COVID-19 pandemic, with competition that continues to increase from day to day, companies are required to be fast and flexible in innovating to meet consumer wants and needs. PT. Emerald Bumi Indonesia in its implementation must be able to survive and continue to strive to direct business activities appropriately. Analyzing and interpreting the movement of variations in consumer needs today is a must for business actors to anticipate production activities, inventory and sales volume so as not to experience excess or shortage [25].

Table 1. Results of Calculation of Exponential Smoothing Method Forecasting

\begin{tabular}{|c|c|c|c|c|c|c|c|}
\hline \multirow{3}{*}{ Month } & \multirow{3}{*}{ Sale (y) } & \multicolumn{6}{|c|}{$a$} \\
\hline & & \multicolumn{2}{|c|}{0,1} & \multicolumn{2}{|c|}{0,5} & \multicolumn{2}{|c|}{0,9} \\
\hline & & Forecast & Error & Forecast & Error & Forecast & Error \\
\hline May & 297 & & & & & & \\
\hline June & 525 & 297 & 228 & 297 & 228 & 297 & 228 \\
\hline July & 430 & 319,8 & 110,2 & 411 & 19 & 502,2 & $-72,2$ \\
\hline August & 376 & 330,82 & 45,18 & 420,5 & $-44,5$ & 437,22 & $-61,22$ \\
\hline Sept & 439 & 335,338 & 103,662 & 398,25 & 40,75 & 382,122 & 56,878 \\
\hline Oct & 525 & 345,704 & 179,296 & 418,625 & 106,375 & 433,312 & 91,688 \\
\hline Nov & 761 & 363,634 & 397,366 & 471,813 & 289,188 & 515,831 & 245,169 \\
\hline Des & 948 & 403,37 & 544,63 & 616,406 & 331,594 & 736,483 & 211,517 \\
\hline Jan 2021 & 911 & 457,833 & 453,167 & 782,203 & 128,797 & 926,848 & $-15,848$ \\
\hline Feb 2021 & 555 & 503,15 & 51,85 & 846,602 & $-291,6$ & 912,585 & $-357,585$ \\
\hline Mar 2021 & 658 & 508,335 & 149,665 & 700,801 & $-42,801$ & 590,759 & 67,242 \\
\hline Apr 2021 & 625 & 523,302 & 101,699 & 679,4 & $-54,4$ & 651,276 & $-26,276$ \\
\hline \multicolumn{2}{|c|}{ Next Periode Forecast } & 533,471 & & 652,2 & & 627,628 & \\
\hline
\end{tabular}

Tabel 2 Results of Calculation of Trend Model Least Square Method

\begin{tabular}{lcccccc}
\hline \multicolumn{1}{c}{ Month } & Sale $(\mathrm{y})$ & Time $(\mathrm{x})$ & $\mathrm{x}^{2}$ & $\mathrm{XY}$ & Forecast & Error \\
\hline May & 297 & -11 & 121 & -3267 & 392,923 & $-95,923$ \\
June & 525 & -9 & 81 & -4725 & 428,301 & 96,699 \\
July & 430 & -7 & 49 & -3010 & 463,678 & $-33,678$ \\
August & 376 & -5 & 25 & -1880 & 499,056 & $-123,06$ \\
Sept & 439 & -3 & 9 & -1317 & 534,434 & $-95,434$ \\
Oct & 525 & -1 & 1 & -525 & 569,811 & $-44,811$ \\
Nov & 761 & 1 & 1 & 761 & 605,189 & 155,811 \\
Des & 948 & 3 & 9 & 2844 & 640,566 & 307,434 \\
Jan 2021 & 911 & 5 & 25 & 4555 & 675,944 & 235,056 \\
Feb 2021 & 555 & 7 & 49 & 3885 & 711,322 & $-156,32$ \\
Mar 2021 & 658 & 9 & 81 & 5922 & 746,699 & $-88,699$ \\
Apr 2021 & 625 & 11 & 121 & 6875 & 782,077 & $-157,08$ \\
Totals & 7050 & 0 & 572 & 10118 & & 0 \\
Average & 587,5 & 0 & 47,667 & 843,167 & & 0 \\
Next period & & & & & 817,455 & $($ Bias) \\
Forecast & & & & & & \\
Intercept & 587,5 & & & & & \\
Slope & 17,689 & & & & & \\
\hline
\end{tabular}

Tabel 3 Error Value Result of Exponential Smoothing Method and Trend-Least Square Method

\begin{tabular}{cccccc}
\hline Metode Peramalan & & Forecast & MAD & MSE & MAPE \\
\hline \multirow{2}{*}{ Exponential Smoothing } & $a=0,1$ & 533,471 & 214,974 & 71324,91 & $31,51 \%$ \\
& $a=0,5$ & 652,2 & 143,364 & 33390,61 & $22,19 \%$ \\
& $a=0,9$ & 627,628 & 130,329 & 28251,23 & $22,004 \%$ \\
Trend Model Least Square & & 817,455 & 132,5 & 23080,47 & $22,25 \%$ \\
\hline
\end{tabular}


From the table above, it can be interpreted that the exponential smoothing method with an alpha of 0.9 has a smaller difference (MAD) of 130.329 with an average difference (MSE) of 23080.47 and a MAPE value of $22 \%$. Although the MSE value of the exponential smoothing $a 0.9$ method is not the smallest value, the small MAD and MAPE values make the exponential smoothing 0.9 an effective method to use in forecasting sales. The error value generated by the exponential smoothing method $a 0.9$ indicates that the method is effective and appropriate to use. Therefore, the company must set a sales target based on the forecasting results that have been calculated using the exponential smoothing $a 0.9$ method for the 2 nd covid-19 pandemic period. The results of sales forecasting in this study strengthen research [5] [11] [26] that the exponential smoothing method is a flexible method based on constant values to smooth it out.

It can be seen that the forecasting results using the exponential smoothing $a 0.9$ method are able to produce a small forecast error value and are suitable for optimizing sales of Power Bumi liquid products. Not only that, the costs incurred during the production process until the product is ready for sale will be more efficient. In achieving optimal sales conditions with the hope that all sales targets can be achieved, all company management must collaborate in planning from production to marketing. Sales forecasting has managerial implications for marketing management, financial management and HR management (labor). Sales forecasting is very influential on marketing management and HR management, with sales forecasting marketing management can find out the number of products that must be promoted and marketed, so that the finished product inventory in the warehouse does not experience excess stock. In doing marketing the marketing team of PT. Zamrud Bumi Indonesia provides opportunities for young people with a part-time work system (freelance) in marketing these products. This can streamline the company's budget, because the company does not need to pay a fixed salary for marketing sales. As for permanent employees, the company has carried out a coordinated division of labor based on their respective abilities, so that does not happen excessive workload. The implication of forecasting on financial management is to provide predictions and opportunities to avoid continuing losses due to the impact of the COVID-19 pandemic.

\section{Conclusion}

From the comparison results of forecasting accuracy values, a suitable method for optimizing liquid fertilizer sales is the exponential smoothing method with a constant $(a) 0.9$ because it has a small difference and error value compared to other methods. Although the exponential smoothing $a 0.9$ method produces a forecast value that is relatively low compared to other methods, which is 627.628 boxes. However, the comparison of products sold and the results of the forecast (forecast) has a relatively small average difference (MSE). It can be interpreted that the exponential smoothing $a 0.9$ method is able to suppress the forecasting error value for the 2 nd period. After getting the forecast results, it can be concluded that the number of products sold for the 2nd covid-19 pandemic period will not differ much from the number of sales in the 1st covid-19 pandemic period. The results of this study strengthen the forecasting results [5][11][26] that the exponential smoothing method is a flexible method based on constant values to smooth it out. The exponential smoothing alpha method of 0.9 obtains an error accuracy (error value) MAD of 130.329; MSE value is 28251.23 and MAPE is 22.004\%. This value is the smallest error value compared to other methods, this method is able to optimize sales of Power Bumi fertilizer products.

\section{Acknowledgement}

Thank you to all those who support this research, the Management Study Program Faculty of Economics Kuningan University, supervisors, family, and friends who always provide great motivation and support.

\section{References}

[1] OECD, "Covid-19: SME Policy Responses," Oecd 2020, no. March, pp. 1-55, 2020, [Online]. Available: https://oecd.dambroadcast.com/pm_7379_119_119680-di6h3qgi4x.pdf.

[2] A. S. Maulana and A. Nubatonis, "Dampak Pandemi Covid-19 terhadap Kinerja Nilai Ekspor Pertanian Indonesia," J. Agribisnis Lahan Kering, vol. 5, no. 4, pp. 69-71, 2020, doi: 10.32938/ag.v5i4.1166.

[3] R. T. Prasetio, "Inventory Control Using Statistics Forecasting on Manufacturing Company," J. Inform., vol. II, no. 2, pp. 136-142, 2014.

[4] Ulia Ulfa, Sumijan, and G. W. Nurcahyo, "Peramalan Penjualan Pupuk Menggunakan Metode Trend Moment," J. Inform. Ekon. Bisnis, vol. 1, no. 4, pp. 8-14, 2019, doi: 10.37034/infeb.v1i4.4.

[5] D. I. Pebri Sentika, A. A. Yusuf, and R. Awaluddin, "PERAMALAN PENJUALAN DENGAN METODE EXPONENTIAL SMOOTHING DAN METODE LEAST SQUARE GUNA MENGOPTIMALKAN PENJUALAN PRODUK NUGGET MAILA," vol. 14, no. 1, pp. 110-118, 2021.

[6] R. Yuniarti, "Analisa Metode Single Exponential Smoothing ( Studi Kasus : Lokatara Dimsum ),” J. Manaj. Bisnis, pp. 29-33, 2020.

[7] C. Rahmad, R. S. Wibowo, and D. Puspitasari, "Peramalan Penjualan Daging Sapi Menggunakan Metode Trend Least Square," $J$. Teknol. Inf. dan Terap., vol. 6, no. 1, pp. 7-11, 2019, doi: 10.25047/jtit.v6i1.104.

[8] E. Widajanti and Suprayitno, "Implementasi Metode Least Square Untuk Memprediksi Penjualan Susu Perah ( Studi Pada Kud Cepogo Kabupaten Boyolali)," Res. Fair UNISRI, vol. 4, no. 1, pp. 439-451, 2020.

[9] S. Kumar Paul, "Determination of exponential smoothing constant to minimize mean square error and mean absolute deviation," Glob. J. Res. Eng., vol. 11, no. 3, pp. 30-34, 2011.

[10] T. D. Andini and P. Auristandi, "Peramalan Jumlah Stok Alat Tulis Kantor di UD Achmad Jaya Menggunakan Metode Double Exponential Smoothing," J. Ilm. Teknol. Inf. Asia, vol. 10, no. 1, pp. 1-10, 2016.

[11] R. Rachman, "Penerapan Metode Moving Average dan Exponential Smoothing pada Peramalan Produksi Industri Garment," J. Inform., vol. 5, no. 1, pp. 211-220, 2018.

[12] R. Yudaruddin, FORECASTING: untuk Kegiatan Ekonomi dan Bisnis. Samarinda: RV Pustaka Horizon Anggota IKAPI, 2019.

[13] R. D. Snyder, A. B. Koehler, and J. K. Ord, "Forecasting for inventory control with exponential smoothing," Int. J. Forecast., vol. 18, no. 1, pp. 5-18, 2002, doi: 10.1016/S0169-2070(01)00109-1.

[14] R. Josenda and C. I. Asmarawati, “Analisa Peramalan Produk Palet Kayu di CV. Barokah Urama,” J. Comasie, vol. 01, pp. 53-61, 2021.

[15] S. Nugroho, "Penerapan Metode Least Square Untuk Sistem Peramalan Penjualan Berbasis Website (Studi Kasus : Ojan Sport Yogyakarta),” Dr. Diss. Univ. Technol. Yogyakarta, 2020. 
[16] Makridakis, Wheelwright, and McGee, Metode dan Aplikasi Peramalan, Second Edi. Jakarta: Binarupa Aksara, 1999.

[17] O. P. Hutajulu, "Kajian Peramalan Permintaan dan Perencanaan Optimasi Produksi Semen Pada Plant 11 PT Indocement Tunggal Prakarsa Tbk," Institut Pertanian Bogor, 2010.

[18] F. Sidqi, I. D. Sumitra, J. Dipati, U. No, and J. Barat, "Peramalan Penjualan Barang Single Variant Menggunakan Metode ARIMA, Trend Analysis , Dan Single (Studi Kasus : Toko Swalayan XYZ ), 2019.

[19] P. D. Sugiyono, Metode Penelitian Kuantitatif, 1st ed. Bandung: Alfabeta, 2018.

[20] D. Aditia, D. Nasution, F. S. Sains, U. Pembangunan, P. Budi, and U. S. Utara, "Dampak Pandemi Covid-19 Terhadap Perekonomian Indonesia," J. Benefita, vol. 5, no. 2, pp. 212-224, 2020.

[21] Minakshi, "Applications of Mathematics in Various Economic Fields," Res. J. Sci. Technol., vol. 9, no. 1, p. 175, 2017, [Online]. Available: https://doi.org/10.5958/2349-2988.2017.00029.8.

[22] D. Firnando, "Analisis Peramalan Penjualan Buncis Super di Gapoktan XXX Bandung Barat," Karya Ilm. Mhs., no. 2, pp. 1-10.

[23] M. Dekker, K. Van Donselaar, and P. Ouwehand, "How to use aggregation and combined forecasting to improve seasonal demand forecasts," Int. J. Prod. Econ., vol. 90, no. 2, pp. 151-167, 2004, doi: 10.1016/j.ijpe.2004.02.004.

[24] J. Heizer and B. Render, Manajemen Operasi: Manajemen Keberlangsungan dan Rantai Pasokan, 11th ed. Jakarta: Salemba Empat, 2015.

[25] S. Aras, İ. Deveci Kocakoç, and C. Polat, "Comparative Study on Retail Sales Forecasting Between Single and Combination Methods," J. Bus. Econ. Manag., vol. 18, no. 5, pp. 803-832, 2017, doi: 10.3846/16111699.2017.1367324.

[26] G. Sbrana and A. Silvestrini, "Random switching exponential smoothing: A new estimation approach," Int. J. Prod. Econ., vol. 211, no. February, pp. 211-220, 2019, doi: 10.1016/j.ijpe.2019.01.038. 